Working Paper 8901

THE EFFECTS OF DISINFLATIONARY POLICIES ON MONETARY VELOCITY

by William T. Gavin and William G. Dewald

William T. Gavin is an assistant vice

president and economist at the Federal

Reserve Bank of Cleveland. William G.

Dewald is deputy director of the Planning and Economic Analysis Staff at the U.S. Department of State. This working paper is a substantially revised version of an earlier paper, "Velocity Uncertainty: An Historical Perspective," which was issued as Working Paper 8704 by the U.S.

Department of State.

Working papers of the Federal Reserve Bank of Cleveland are preliminary materials circulated to stimulate discussion and critical comment. The views stated herein are those of the authors and not necessarily those of the Department of State, of the Federal Reserve Bank of Cleveland, or of the Board of Governors of the Federal Reserve System.

February 1989 


\begin{abstract}
Is the recent decline in monetary velocity the result of deregulation or disinflation? Studies of this issue using recent U.S. data generally attribute the decline to deregulation. We examine the experience in the United States back to 1907 and the recent experience, the past 30 years, in a group of 39 countries. Our results show a systematic relation between unexpected changes in the money-income relationship and changes in the trends of inflation rates.

By our calculations, a policy that reduced average inflation by 10 percentage points from one business cycle to the next would be associated with an average 3 to 5 percentage-point reduction in velocity growth trends. This effect is somewhat smaller than the U.S. record for the 1980s, especially for M1. We do not offer these results as a method for adjusting monetary targets during a disinflation; rather, our results offer further evidence that the failure to commit to a stable price policy tends to destabilize the economy.
\end{abstract}




\section{THE EFFECTS OF DISINFLATIONARY POLICIES ON MONETARY VELOCITY}

The U.S. economy in the 1980 s saw a decline in the trend growth rate of monetary velocity--the ratio of nominal GNP to the money supply. This unexpected development was reflected in the systematic overprediction of inflation and nominal GNP growth by econometric models and economic forecasters. Lucas (1976) showed that econometric models would err when simulating policy alternatives or when forecasting over a horizon in which policy had changed.

Was the recent decline in monetary velocity the result of deregulation or disinflation? Studies of this issue have found little effect from the disinflation policy. These studies have focused on U.S. data from 1959 to the 1980s. Rasche (1986, 1988) and Roley (1985) find that including inflation or inflation expectations as explanatory variables does not pick up the changes in velocity that occurred in the early 1980s. Both authors attribute the shift in velocity to deregulation because the shift is explained by dumm variables entered for periods of regulatory change. The problem, of course, is that the disinflation policy and the deregulation occurred over the same period.

Poole (1988) argues that including long-term interest rates in a standard log-linear money-demand function tends to capture the effect of changing inflation trends. These equations, however, also made large errors in forecasting money demand in the 1980s. But perhaps we should not be convinced by the standard regression results. It does not seem appropriate to use short-term movements in money growth, inflation, or long-term interest rates 
as a proxy for the disinflation policy. Disinflation policies are irregular events; indeed, the entire period for which the Federal Reserve maintains consistent data for the monetary aggregates, 1959:Q1 to the present, contains few episodes that might be accurately portrayed as including a disinflation policy.

In this paper, we consider the effect of disinflation policies on the velocity relationship by examining the experience in the United States back to 1907 and the recent experience - the past 30 years - in a group of 39 countries. Our results show a systematic relation between unexpected changes in the money-income relationship and changes in the trends of inflation rates. By our calculations, a policy that reduced average inflation by 10 percentage points from one business cycle to the next would be associated with an average 3 to 5 percentage-point reduction in velocity growth trends. This effect is somewhat smaller than the U.S. record for the 1980s, especially for M1. We do not offer these results as a method for adjusting monetary targets during a disinflation; rather, our results offer further evidence that the failure to commit to a stable price policy tends to destabilize the economy.

\section{Why Should Disinflation Policies Lead to Lower Velocity Growth?}

People hold money to reduce transaction costs. The opportunity cost of holding money is the real interest foregone from not holding bonds and the depreciation of the value of cash holdings due to inflation. At the margin, people will want to hold more money relative to their income and expenditures when the cost of holding money falls. Therefore, when inflation declines we expect velocity, the ratio of income to money, to fall.

The dynamics of this process become complex when we introduce forward-1ooking expectations. Consider the conventional log-1inear 
money-demand function. When we combine this money-demand model with a money-supply policy and solve for the inflation rate, we find that inflation today is a function of expected future money growth. ${ }^{1}$ Any discrete change in the expected trend in money growth will lead to a discrete change in the level of money demand. So, while changes in the trend growth rate of the money supply lead to equal changes in the trend inflation rate, there will be a temporary period of negative correlation between inflation and money growth due to the one-time shift in money demand.

Assume for simplicity that real income and transaction technologies are fixed. If the central bank had a policy of stable inflation (zero or some other constant rate), the money growth rate would equal the inflation rate. Expectations of inflation would not change from period to period, and the implied velocity trend growth would be zero. If the central bank had a policy of increasing the inflation rate at a constant acceleration rate each period, then inflation expectations would be rising at a constant rate, money growth would be less than the inflation rate, and velocity would grow at a constant rate.

A discrete shift in the level of velocity occurs whenever there is a change from one money growth rate to another. In Figure 1 we illustrate a hypothetical economy showing the effect of abrupt changes in the money growth trend under the assumption that the public expects the current money growth trend to be permanent.

The period from 0 to $\mathrm{T}_{1}$ represents a steady state with zero inflation. The money growth rate is zero, inflation is zero, and velocity is constant, as shown in the bottom panel of Figure 1 . At $T_{1}$ the equilibrium money growth rate is raised to 5 percent. The price level and velocity jump to a new level; inflation rises from 0 to 5 percent, but velocity growth is still zero. 
At $\mathrm{T}_{2}$, the monetary authority surprises the public again with an increase in the money growth trend to 10 percent - - and the price level and velocity jump again. At $\mathrm{T}_{3}$, an abrupt disinflation policy is adopted. The money growth trend is lowered to the original level.

of course, it is inappropriate to expect people to be completely surprised by current or future changes in the course of policy. In the real world we expect some anticipation of policy changes and perhaps a period of learning after the policy changes are made. Changes in prices may lead or lag the actual implementation of a disinflation policy. A longer lag is more likely when the monetary authority lacks credibility. While no one expects the economy to behave in the stylistic fashion depicted in Figure 1, the figure captures the essence of a process that we think has been at work in the United States since World War II.

The Framework for Analyzing the Effects of Disinflation on Velocity

The velocity relationship has been measured in various ways. Many people have used a leading velocity concept because changes in money tend to lead changes in income. In this paper we use the following version of the St. Louis equation to define the velocity relation:

(1) $\nabla \ln (G N P)_{t}=c+\sum_{j=0}^{n} b_{j} \nabla \ln (M)_{t-j}+e_{t}$ where

GNP = nominal gross national product, $M$ - money stock defined alternatively as the monetary base, $M 1$, and $M 2$, $e=$ error term, where $e_{t}$ iid $N\left(0, \sigma^{2}\right)$.

We examine the out-of-sample forecast errors from this equation and their 
relation to changes in the expected monetary growth trend. Consider the form of the velocity process implied by the St. Louis equation:

(2) $\nabla v_{t}=-\nabla \ln (M)_{t}+c+\sum_{j=0}^{n} b_{j} \nabla \ln (M)_{t-j}+e_{t}$, where $v_{t}=\ln (G N P / M)_{t}$.

This equation implies that the velocity growth trend is equal to a constant plus a proportion $\left(\sum \mathrm{b}_{j}-1\right)$ of the money growth trend. This equation can work well in a wide variety of economic structures as long as the process generating the money supply is well-behaved. If there are no abrupt changes in the trend of money growth, then a weighted sum of past money growth may be a good predictor of future money growth. However, this equation will err when used to predict nominal GNP growth in the presence of a change in policy. The error will be largest in the near term and will gradually disappear as the forecast horizon is lengthened.

One implication of this finding is that an empirical researcher estimating the St. Louis equation -- or some other simple expression of the quantity theory - - will want to choose a time period that excludes abrupt changes in the trend money-growth rate. Periods of abrupt policy changes will be avoided because they include the transitory periods when prices and money will not be moving together. For example, we find that most studies of the St. Louis equation omit the Korean War experience. One might think of the U.S. experience from 1955 to the present as being depicted in Figure 1. Between 1955 and 1980, the trend of inflation and money growth steadily increased (as 
illustrated in Figure 1 from period 0 to $\mathrm{T}_{3}$ ). In the early $1980 \mathrm{~s}$, the trend of inflation was reversed.

of course, the illustration is not exact. Rather than a decline in the price level, there was a jump in the money supply (spread over several years). Nevertheless, the effect on velocity is the same (see the bottom panel of Figure 1). The jump in the money supply should be expected because the Federal Reserve does not have ultimate goals for the money stock. Rather, goals are formulated in terms of prices and income. Monetary targets are used as intermediate targets to achieve those goals. If the public and the Federal Reserve expect a one-time increase in real money demand following the implementation of a disinflation policy, then the Fed would be expected to accommodate this demand shift with an equal shift in the money supply in order to maintain a given path for income and prices. In practice, because the Fed uses the federal funds rate as an operating instrument, the Fed tends to accommodate shifts in nominal money demand automatically.

Therefore, the expectation that there will be a reduction in the monetary growth trend over the long run will be accompanied by a decline in the inflation rate and a temporary increase in the observed money stock. Ideally, we would like to measure the excess of money supply over real money demand. In the absence of a well-defined measure of real money demand, we use the average inflation rate over an extended period as a measure of the expected trend in money supply growth.

Experience in the United States: 1907 to 1987

We use historical data for money and nominal income starting in 1907:Q3 to examine the forecasting error of the St. Louis equation. We want to see whether equation (1) systematically overpredicted nominal GNP growth in 
periods when there was a decline in the trend inflation rate and whether it underpredicted nominal GNP growth when there was an increase in the trend inflation rate. Under the assumptions implied by this equation, there should be no systematic correlation between the forecast errors and the change in the average inflation rates. We examined this proposition under three alternative definitions of money: the monetary base, M1, and M2. ${ }^{3}$ Equation (1) was estimated for a series of samples that included three consecutive business cycles as measured from trough to trough. Equations estimated separately for each aggregate in each sample were used to forecast nominal GNP growth in the next cycle.

We began by estimating this model for the period 1908:Q4 to 1919:Q1. Each estimated equation was then used with actual monetary data to predict nominal GNP growth over the course of the next business cycle. The equations were updated seriatim by adding the data from the forecast cycle and dropping the data from the first cycle. This procedure was followed through the last forecast interval, 1983:Q1 to 1987:Q1, which is not a full cycle. Overall, there are 15 forecast intervals for the base and M2. There are only 13 forecast intervals for M1 because of the lack of quarterly information about the split between demand and time deposits before 1914:Q3 .

The first three columns in Table 1 list the estimated standard errors for each aggregate in each of the overlapping estimation periods. The standard regression errors for all equations reflect the pattern of variance in GNP growth. There was a large decline in the variance of GNP growth and in the standard error of the forecasting equations after WW II. Averages for the entire sample, for the periods before 1946, and for the periods after 1946 are 
shown at the bottom of each table. M2 has the lowest standard error on average for the entire sample, and $M 1$ has the lowest standard error in the postwar era.

Adjusted $\mathrm{R}$-squares are also reported in Table $1 .^{4} \mathrm{Ml}$ yields the most consistent in-sample explanation of nominal GNP growth. The results for the other aggregates vary over time. The monetary base never explains much of the in-sample variation of nominal GNP growth.

The out-of-sample statistics (shown in Table 2) should confirm the results of the in-sample statistics if the forecasting model is stable over time. The root mean square errors (RMSEs) reflect a common problem in economic forecasting. The specification that works best in any particular sample does not always work best in the next period. In our case, Ml had the most explanatory power in-sample, but M2 produced the best out-of-sample forecasts. If we consider only the subsample for which M1 quarterly data were available, the RMSEs for M2 were lowest on average. The average for M2 is 9.15 percent at annual rates for the periods from 1924 to 1987 . M1 did better than M2 in the 1950s and the 1970s. M1 has done so poorly in the 1980s that it does worse on average than the monetary base over the entire postwar period, even though it performed better than the base for the 30 years before $1980 .^{5}$

While the absolute size of variation in velocity was much higher before WWII, the perception that there was a large increase in uncertainty about velocity in the $1980 \mathrm{~s}$ is due to the relative increase in the forecast errors. There were only two business cycles in which one could uniformly reject the hypothesis that forecast errors (for all definitions of velocity) were generated by the same model used to make the forecast: the cycles from 1933:Q2 
to 1938:Q2 and from 1980:Q4 to 1982:Q4. Even though velocity was more variable in some earlier periods, the relative uncertainty about quarterly movements in velocity was as high in the early 1980 s as it has ever been. Cycle-average forecast errors are shown on the right side of Table 2 . There were very large average forecast errors before 1946, although these errors were not large relative to the standard error of the forecasting equations. The forecasts were relatively unbiased after 1946 except in the 1946-1949 business cycle and in the most recent period (1983-1987). The large bias in the forecast using $M 1$ in the most recent cycle is one source of current disenchantment with monetary targeting. Tests show several significant errors in the forecast of the velocity growth trend scattered throughout the 80 -year period. In recent years we see that there was a significant underprediction of the GNP growth trend for all of the aggregates for the period 1975:Q2 to 1980:Q3. This was followed by significant overprediction of GNP growth trends in the 1980s.

To what extent are these large errors associated with changes in monetary policy? To answer this question, we regressed the mean forecast error on the change in the average inflation rate for the most recent cycle in the estimation period to the average in the forecast cycle. Under the hypothesis of our regression model, the mean forecast error is distributed normally with zero mean and variance equal to the estimated variance of the error in the regression equation divided by the square root of the number of quarters in the forecast interval.

We assume that the expected variances of the forecast errors for each cycle are equal to the estimated variance of the error in the forecasting equations. Since these expected variances differ so much over the past 80 years, we cannot assume that the errors will be homoscedastic. While an 
ordinary least squares (OLS) regression of the mean forecast error on other variables will result in unbiased estimates of the slope parameters, it may yield inefficient estimates of the variances of the parameter estimates and incorrect t-statistics. To avoid this problem, we weighted the mean forecast errors and the right-hand-side variables by the reciprocal of the expected standard deviation of the mean forecast error and then used OLS on the weighted variables.

Results in Table 3 show that changes in the inflation trend were positively related to the cycle-average forecast error. As expected, a disinflation policy raised the demand for real balances and lowered the velocity growth rate.

\section{Cross-Country Evidence: 1957 to 1985}

Further evidence is presented from a cross-sectional study of 39 countries. For each country, we compare the out-of-sample forecasting errors of equation (1) in the 1980 s to the change in the expected money-supply-growth trend. As was the case for the United States, we find that the St. Louis equation systematically overpredicts nominal GNP growth following a reduction in the expected money-supply-growth trend and systematically underpredicts nominal GNP growth following an increase in the expected money-supply-growth trend.

The cross-country data come from the International Financial Statistics tape compiled by the International Monetary Fund. ${ }^{6}$ Because quarterly GNP data are relatively scarce, we have used annual data through 1979 to estimate the country models. The equation included the contemporaneous value and a one-year lag of M1 growth. We used quarterly Consumer Price Index (CPI) data, however, to measure inflation trends in each of the countries. In general, 
GNP data are measured with substantial error, especially in some of the less-developed countries. It seems that the CPI is one of the most carefully constructed economic indexes. By using the CPI to measure the change in the inflation trend, we reduce the possibility that our results are due to. measurement error in the construction of the GNP deflator.

Our forecasting equation should underpredict GNP growth for those countries that have had an increase in the inflation trend and should overpredict GNP growth for those countries that have had a decline in the inflation trend. Table 4 lists the countries included in the sample and the beginning and end of the sample data for each country. Also listed are the summary statistics for each country used in the forecasting experiment. In order, we list unadjusted R-squared for the forecasting equation estimated through 1979, the mean forecast error for the 1980s, and the change in the inflation trend (measured as the average quarterly growth rate of the CPI in the 1980s minus the quarterly average growth rate from 1973:Q2 through 1979:Q4). Twenty-two of the countries had lower inflation trends in the early 1980s than they had in the 1970s, and seventeen had higher trends. The correlation between forecast errors and the change in the inflation trend is shown in Table 5. We regress the mean forecast errors for each country on the change in the inflation trend. The errors of the St. Louis model are clearly correlated with the change in the inflation trends.

Chart 1 shows the scatter diagram of the average forecast error for each country plotted against the change in the inflation trend. Four outliers have very high inflation rates and very large changes in the inflation trend: Bolivia, Brazil, Mexico, and Peru. We reproduce the regression results 
excluding these countries. The results, also shown in Table 5, confirm our conclusions for countries with small to moderate changes in inflation as well as countries that end hyperinflations.

Conclusion

Evidence from 80 years of U.S. experience and a 30 -year cross-section of 39 countries shows that the velocity relation embodied in the $S t$. Louis equation was systematically affected by disinflation (and inflation) policies. Velocity typically declines relative to trend when disinflation policies are adopted. This result is predicted by traditional money-demand theory with forward-looking expectations.

For the experience covered by our data, a policy that reduced average inflation by 10 percent from one business cycle to the next would be associated with an average 3 to 5 percent reduction in velocity growth trends. While a disinflation policy is expected to lead to a decline in the velocity growth trend, the size and timing of the decline error are still uncertain. This is partly because the parameters of the forecasting equation are likely to change with a policy shift, and partly because central banks do not commit to long-run monetary trends. Even if we knew how the forecasting model would err in the presence of a policy regime shift, we could not predict inflation with confidence because we cannot predict future money-supply trends.

One might conclude from our analysis that the Federal Reserve should use nominal GNP or the price level itself as the guide to policy. As in Haraf (1986), the occurrence of persistent deviations of velocity from trend implies that simple money-growth rules may not be the best way to reduce inflation gradually. Nevertheless, we do not think this is the most important point to be made. Rather, our results show that uncertainty about future policies can 
destabilize the economy. Policymakers could remove this uncertainty if they were able to commit to a long-run nominal GNP or price level target: the short-run variability in velocity and money growth could then be safely ignored. Otherwise, the public is left with the difficult task of predicting the future behavior of policymakers. 


\section{Footnotes}

1. See Cagan (1956), Friedman (1969), and Sargent (1986) for further discussions of this model of money demand.

2. This equation is in the tradition of the St. Louis equation that was introduced by Andersen and Jordan (1968).

3. The data used in this study come from a variety of sources. M1 and M2: May 1907 to December 1958 from Friedman and Schwartz (1963); and January 1959 to March 1987 from the Board of Governors of the Federal Reserve System. Values for Ml were semiannual until June 1914. Monetary base: May 1907 to December 1918 from Friedman and Schwartz (1963); and January 1919 to March 1987 from the Federal Reserve Bank of St. Louis, adjusted for changes in reserve requirements, but not seasonally adjusted. The Census X-11 program in SAS was used to seasonally adjust this monthly series, which was then used to get quarterly averages. Data series from different sources that were used in statistical analysis were spliced by transforming the early series to growth rates and computing revised level series based on the actual level of the most recent series. Commercial paper rate: Board of Governors of the Federal Reserve System. The early values for this interest rate are published in Banking and Monetary Statistics, and recent values are published in the Federal Reserve Bulletin. Quarterly data were computed as the average of monthly values. GNP and GNP deflator: 1907:Q2 to 1947:Q4 from Gordon (1982); and 1948:Q4 to 1987:Q1 from the Bureau of Economic Activity.

4. While the explanatory power of this forecasting model is quite low in an absolute sense, there was not a significant amount of serial correlation in the error term for the cases before 1927 or after 1950 . While this is a very naive forecasting model, it does about as well in recent years as more elaborate models. For example, Karamouzis and Lombra (1988) report that the RMSE of the Federal Reserve staff's quarterly nominal GNP forecast was 4.2 percent at an annual rate for the period between 1973:Q1 and 1982:Q4. This is somewhat greater than the RMSEs from the M1 equation, but about the same as the RMSEs for the other aggregates during this period.

5. The relatively poor performance of $M 1$ is probably due to the relaxation of the prohibition against paying interest on checkable accounts. See Rasche (1988) for an argument that all of the increase in uncertainty about velocity is due to deregulation. Using M1A in place of M1 in the 1980s does not help overall. The error using M1A was very large in the 1980:Q4 to 1982:Q4 cycle and offsets some improvement in the recent cycle. For a discussion of MIA and its usefulness as an indicator and target of policy, see Darby, Mascaro, and Marlow (1987) and Gavin and Pakko (1987). 
6. We started with the 46 countries included in the study by Kormendi and Meguire (1984). Our data come from a more recent tape supplied by the International Monetary Fund (IMF). Taiwan was eliminated from the tape by the IMF. We eliminated six other countries that had less than 21 annual observations so that we were left with 39 countries in our data set. 


\section{References}

Andersen, Leonall C., and Jerry L. Jordan. "Monetary and Fiscal Actions: A Test of Their Relative Importance," Review, Federal Reserve Bank of St. Louis, vol. 50 (November 1968), pp. 11-23.

Cagan, Phillip. "The Monetary Dynamics of Hyperinflation," in Studies in the Quantity Theory of Money, edited by Milton Friedman, The University of Chicago Press, Chicago (1956), pp. 25-117.

Darby, Michael R., Angelo R. Mascaro, and Michael L. Marlow. "The Empirical Reliability of Monetary Aggregates as Indicators: 1983-1986," Research Paper No. 8701, U.S. Department of the Treasury, 1987.

Friedman, Milton. The Optimum Quantity of Money and other Essays, Aldine Publishing Company, Chicago (1969).

Friedman, Milton, and Anna Schwartz. A Monetary History of the United States: 1867-1960, Princeton University Press, Princeton, N.J. (1963).

Gavin, William T., and Michael R. Pakko. "M1A -. M.I.A.?", Economic Commentary, Federal Reserve Bank of Cleveland, July 1, 1987.

Gordon, Robert J. "Price Inertia and Policy Ineffectiveness in the United States, 1890-1980," Journal of Political Economy, vol. 90 (December 1982), pp. $1087-1117$.

Haraf, William S. "Monetary Velocity and Monetary Rules," Cato Journal, vol. 6 (Fall 1986), pp. 641-662.

Karamouzis, Nicholas, and Raymond Lombra. "Federal Reserve Policymaking: An Overview and Analysis of the Policy Process," presented at the Carnegie-Rochester Public Policy Conference on April 22, 1988.

Kormendi, Roger C., and Philip G. Meguire. "Cross-Regime Evidence of Macroeconomic Rationality," Journal of Political Economy, vol. 92 (October 1984), pp. 875-908.

Lucas, Robert E. Jr. "Econmetric Policy Evaluation: A Critique," in The Phillips Curve and Labor Markets, Carnegie-Rochester Conference Series on Public Policy, vol. I (1976), pp. 19-46.

Poole, William. "Monetary Policy Lessons of Recent Inflation and Disinflation," Journal of Economic Perspectives, vol. 2, no. 3 (Summer 1988), pp. 73-100. 
Rasche, Robert H. "Demand Functions for U.S. Money and Credit Measures," presented in a Conference on Monetary Aggregates and Financial Sector Behavior in Interdependent Economies at the Board of Governors of the Federal Reserve System, May 26, 1988.

Rasche, Robert H. "Ml-Velocity and Money Demand Functions: Do Stable Relationships Exist?" Presented at the Carnegie-Rochester Conference on Public Policy on November 21, 1986.

Roley, V. Vance. "Money Demand Predictability," Journal of Money, Credit, and Banking, vol. 17, no.4, part 2 (November 1985), 611-641.

Sargent, Thomas J. Rational Expectations and Inflation, Harper and Row; New York, 1986. 


\section{Figure 1 An Illustration of Velocity Shifts Due to Policy}

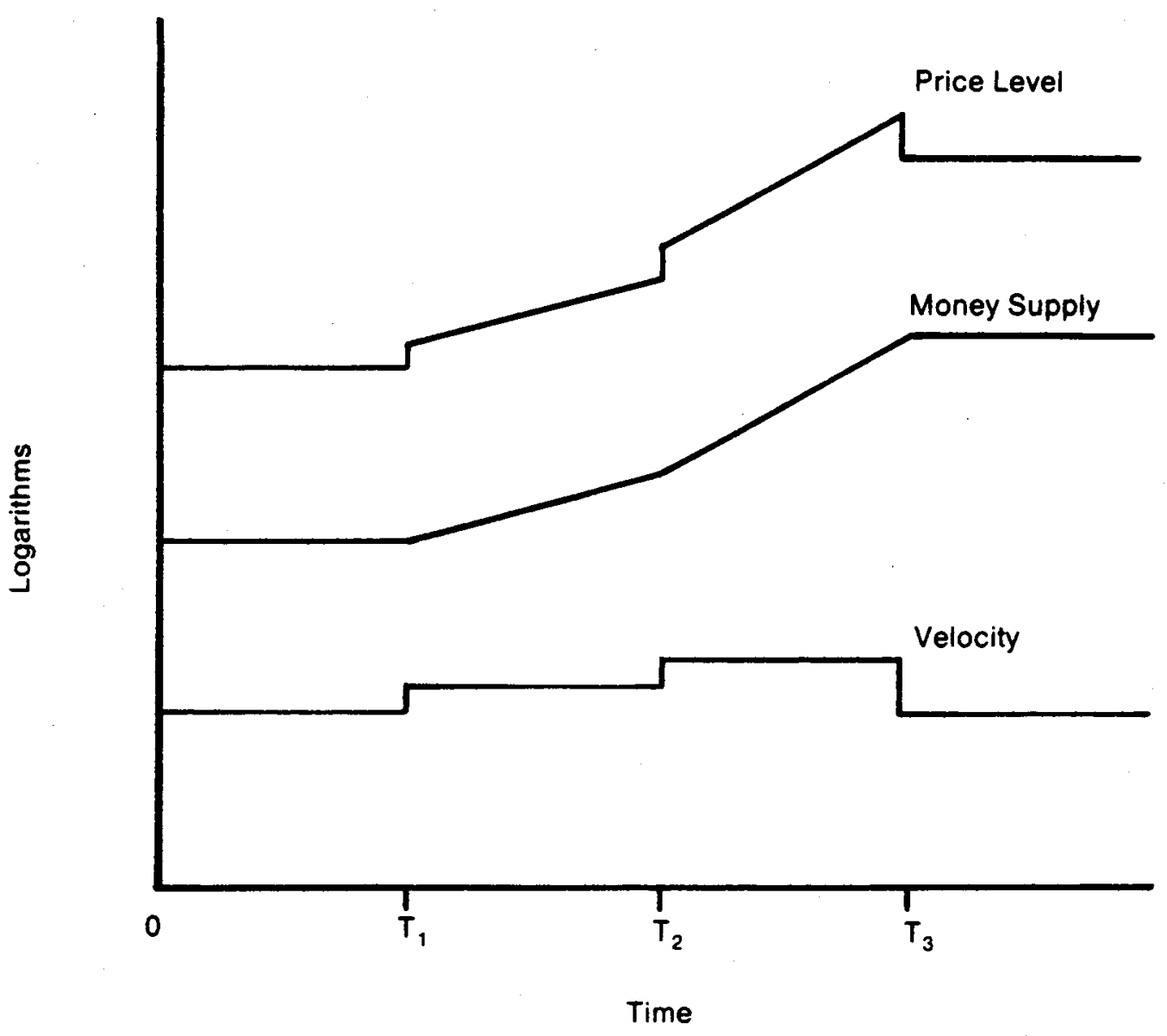


Table 1. In-Sample Statistics

\begin{tabular}{|c|c|c|c|c|c|c|}
\hline & imated & andard & cors & Adj & d R-S & res \\
\hline Estimation & - . & $\ldots$ & $\cdots$ & $\cdots$ & 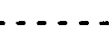 & $\cdots$ \\
\hline Period & Base & M1 & M2 & Base & M1 & M2 \\
\hline $08: 4-19: 1$ & 12.97 & & 12.16 & 0.17 & & 0.27 \\
\hline $12: 2-21: 3$ & 16.58 & & 15.83 & 0.28 & & 0.34 \\
\hline $15: 1-24: 3$ & 17.74 & 17.02 & 17.61 & 0.25 & 0.31 & 0.26 \\
\hline $19: 2-27: 4$ & 15.37 & 13.92 & 13.47 & 0.20 & 0.34 & 0.39 \\
\hline $21: 4-33: 1$ & 17.82 & 12.51 & 11.41 & -0.01 & 0.50 & 0.59 \\
\hline $24: 4-38: 2$ & 20.50 & 17.96 & 15.63 & 0.05 & 0.27 & 0.45 \\
\hline $28: 1-45: 4$ & 21.54 & 18.04 & 17.40 & 0.00 & 0.30 & 0.35 \\
\hline $33: 2-49: 4$ & 16.93 & 16.28 & 15.75 & -0.01 & 0.07 & 0.13 \\
\hline $38: 3-54: 2$ & 12.37 & 10.79 & 11.67 & 0.00 & 0.24 & 0.11 \\
\hline $46: 1-58: 2$ & 7.14 & 5.87 & 6.69 & -0.03 & 0.30 & 0.10 \\
\hline $50: 1-61: 1$ & 6.46 & 5.38 & 6.59 & 0.00 & 0.31 & -0.04 \\
\hline $54: 3-70: 4$ & 3.95 & 3.33 & 3.65 & 0.03 & 0.31 & 0.17 \\
\hline $58: 3-75: 1$ & 3.69 & 3.28 & 3.48 & 0.08 & 0.27 & 0.18 \\
\hline $61: 2-80: 3$ & 3.56 & 3.22 & 3.52 & 0.13 & 0.29 & 0.15 \\
\hline $71: 1-82: 4$ & 4.44 & 4.30 & 4.64 & 0.11 & 0.16 & 0.03 \\
\hline & & & & & & \\
\hline Average & 6.00 & 12.07 & 10.15 & 0.08 & 0.28 & 0.23 \\
\hline Pre-1946 & 17.50 & 15.89 & 14.79 & 0.13 & 0.35 & 0.38 \\
\hline Postwar & 4.88 & 4.23 & 4.76 & 0.05 & 0.28 & 0.10 \\
\hline
\end{tabular}

Source: Authors. 
Table 2. Out-of-Sample Statistics

\begin{tabular}{|c|c|c|c|c|c|c|}
\hline \multirow{4}{*}{$\begin{array}{l}\text { Forecast } \\
\text { Horizon }\end{array}$} & \multicolumn{3}{|c|}{ Root Mean Square Errors } & \multicolumn{3}{|c|}{ Cycle-Average Forecast Errors } \\
\hline & & & & & & - \\
\hline & Base & M1 & M2 & Base & M1 & M2 \\
\hline & & & & & & \\
\hline $19: 2-21: 3$ & $22.03 *$ & & $20.23 *$ & -2.49 & & $-9.93 *$ \\
\hline $21: 4-24: 3$ & 15.75 & & 15.85 & 3.32 & & 3.23 \\
\hline $24: 4-27: 4$ & 7.94 & 10.29 & 9.55 & 0.25 & 1.77 & 0.05 \\
\hline $28: 1-33: 1$ & $29.90 *$ & 15.14 & 13.62 & $-18,66 *$ & $-5.90 \#$ & 0.97 \\
\hline $33: 2-38: 2$ & $36.08 *$ & $28.07 *$ & $26.33 *$ & 20.17 & -1.77 & $5.28 *$ \\
\hline $38: 3-45: 4$ & 20.80 & 17.48 & $18.46 \#$ & 2.55 & $-6.64 *$ & -0.12 \\
\hline $46: 1-49: 4$ & 9.31 & 11.12 & 8.83 & 6.34 & $8.81 \#$ & 4.67 \\
\hline $50: 1-54: 2$ & 7.93 & 6.99 & 7.75 & -1.22 & 0.24 & -1.34 \\
\hline $54: 3-58: 2$ & 6.46 & 4.36 & 6.09 & -4.35 & -0.45 & -2.90 \\
\hline $58: 3-61: 1$ & 5.42 & 5.43 & 5.88 & -1.28 & 0.33 & -3.02 \\
\hline $61: 2-70: 4$ & 3.62 & 4.42 & 2.99 & 1.44 & $-2.00 *$ & 0.62 \\
\hline $71: 1-75: 1$ & 3.99 & 3.73 & 4.13 & 0.42 & 0.28 & -0.07 \\
\hline $75: 2-80: 3$ & 4.36 & 3.74 & 4.47 & $1.56 *$ & $1.15 \#$ & $1.56 *$ \\
\hline $80: 4-82: 4$ & $6.68 *$ & $7.62 *$ & $6.48 *$ & -1.60 & $-2.60 *$ & -1.73 \\
\hline $83: 1-87: 1$ & 4.29 & $8.55 *$ & 4.29 & $-3.46 *$ & $-6.61 *$ & $-2.26 *$ \\
\hline \multicolumn{7}{|c|}{ } \\
\hline \multirow{3}{*}{$\begin{array}{l}\text { Average } \\
\text { Pre-1946 } \\
\text { Postwar }\end{array}$} & 12.30 & 9.77 & 10.33 & 0.20 & -1.03 & -0.33 \\
\hline & 22.08 & 17.74 & 17.34 & 0.86 & -3.13 & -0.09 \\
\hline & 5.78 & 6.22 & 5.66 & -0.24 & -0.09 & -0.50 \\
\hline \multicolumn{7}{|c|}{$\begin{array}{l}\text { * Indicates that the root mean square error is significantly greater } \\
\text { than the estimated standard error of the forecast equation or the } \\
\text { forecast error is different from zero at the } 5 \text { percent critical level. }\end{array}$} \\
\hline \multicolumn{7}{|c|}{$\begin{array}{l}\text { \# Indicates that the root mean square error is significantly greater } \\
\text { than the estimated standard error of the forecast equation or the } \\
\text { forecast error is different from zero at the } 10 \text { percent critical level }\end{array}$} \\
\hline
\end{tabular}

Source: Authors. 
Table 3. Average Forecast Errors and Changes in Economic Trends (United States Experience)

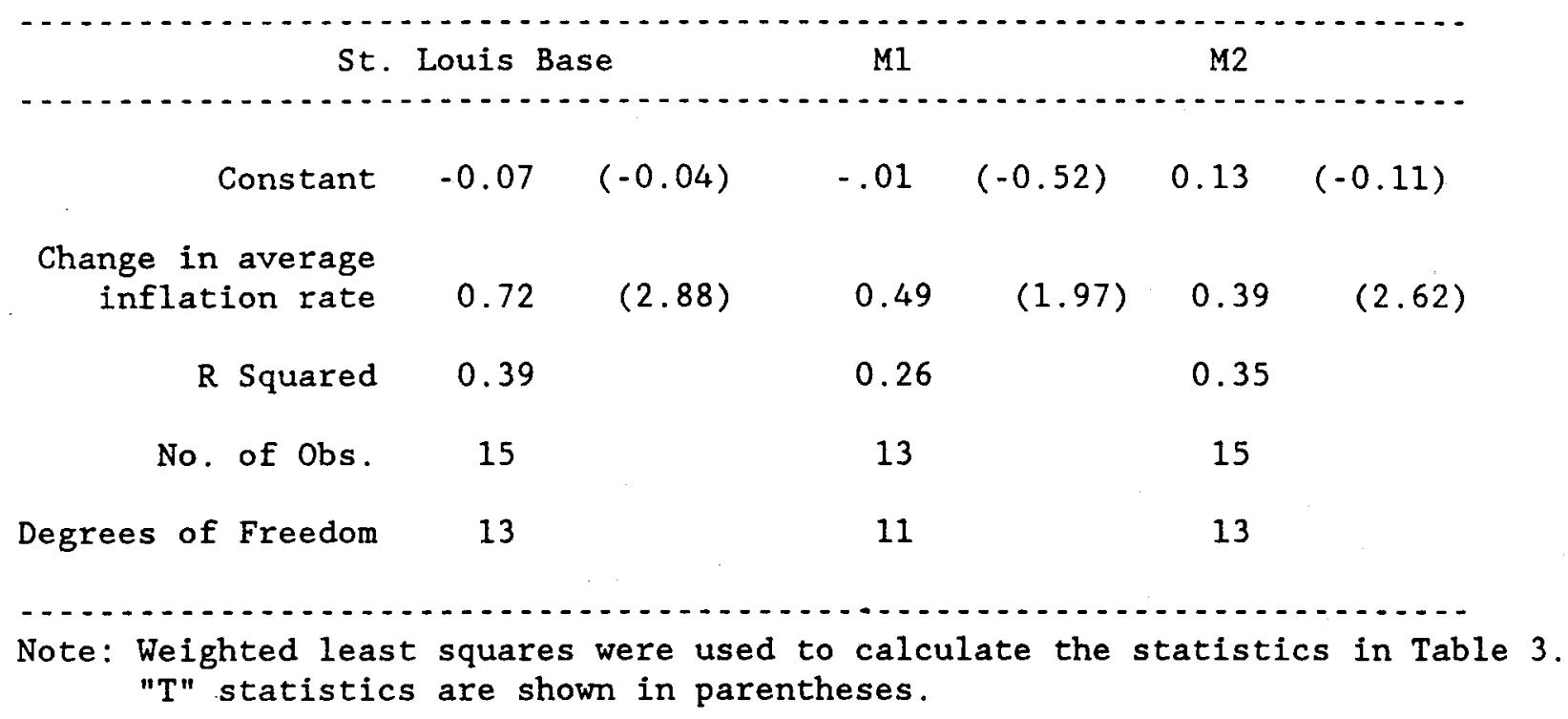

Source: Authors. 


\begin{tabular}{|c|c|c|c|c|c|}
\hline Country & $\begin{array}{l}\text { Samp } \\
\text { Peri }\end{array}$ & & $\begin{array}{l}\text { Unadjusted } \\
R \text {-squared }\end{array}$ & $\begin{array}{l}\text { Average Forecast } \\
\text { Error }\end{array}$ & $\begin{array}{l}\text { Change i } \\
\text { Inflatio }\end{array}$ \\
\hline Australia & 1957 & -84 & 0.63 & -0.49 & -3.42 \\
\hline Austria & 1957 & -84 & 0.29 & -0.29 & -1.18 \\
\hline Belgium & 1957 & -84 & 0.28 & -0.81 & -1.00 \\
\hline Bolivia & 1962 & -83 & 0.39 & 20.96 & 105.72 \\
\hline Brazil & 1963 & -84 & 0.47 & 25.51 & 54.98 \\
\hline Canada & 1957 & -84 & 0.08 & -0.09 & -1.43 \\
\hline Colombia & 1957 & -84 & 0.52 & 1.24 & -0.35 \\
\hline Denmark & 1957 & -84 & 0.17 & -2.35 & -2.67 \\
\hline Dominican Rep. & 1957 & -83 & 0.22 & 0.22 & 3.02 \\
\hline Ecuador & 1957 & -84 & 0.73 & 4.86 & 9.12 \\
\hline El Salvador & 1957 & -85 & 0.78 & -0.62 & 1.51 \\
\hline Finland & 1957 & -84 & 0.41 & -0.26 & -3.45 \\
\hline France & 1957 & -84 & 0.06 & 0.19 & -0.31 \\
\hline Greece & 1957 & -84 & 0.38 & 4.52 & 3.07 \\
\hline Guatemala & 1957 & -83 & 0.70 & 0.35 & -3.70 \\
\hline Honduras & 1962 & -85 & 0.58 & -1.07 & -0.47 \\
\hline Iceland & 1957 & -84 & 0.83 & -3.81 & 5.22 \\
\hline Ireland & 1957 & -82 & 0.51 & 6.30 & 2.60 \\
\hline Italy & 1957 & -84 & 0.25 & 5.18 & -1.41 \\
\hline Japan & 1957 & -84 & 0.31 & -2.48 & -6.46 \\
\hline Mexico & 1957 & -84 & 0.76 & 12.39 & 27.22 \\
\hline Netherlands & 1957 & -85 & 0.35 & -3.58 & -2.61 \\
\hline New Zealand & 1957 & -82 & 0.40 & 2.66 & -1.19 \\
\hline Norway & 1957 & -84 & 0.52 & 1.70 & 0.94 \\
\hline Paraguay & 1957 & -84 & 0.55 & 5.97 & -0.02 \\
\hline Peru & 1960 & -84 & 0.46 & 9.94 & 35.75 \\
\hline Philippines & 1957 & -84 & 0.62 & 4.90 & 4.27 \\
\hline Portugal & 1957 & -82 & 0.46 & 1.23 & -0.12 \\
\hline South Africa & 1957 & -84 & 0.55 & -6.50 & 1.90 \\
\hline Spain & 1957 & -84 & 0.63 & 2.98 & -4.51 \\
\hline Sri Lanka & 1957 & -84 & 0.41 & 6.01 & 5.12 \\
\hline Sweden & 1960 & -82 & 0.29 & -0.48 & 0.25 \\
\hline Switzerland & 1957 & -84 & 0.34 & 0.74 & -0.07 \\
\hline Thailand & 1957 & -84 & 0.65 & -0.28 & -3.89 \\
\hline Turkey & 1962 & -83 & 0.85 & 1.88 & 9.10 \\
\hline United Kingdom & 1957 & -84 & 0.70 & -3.42 & -6.40 \\
\hline United States & 1957 & -84 & 0.69 & -2.32 & -2.34 \\
\hline Venezuela & 1957 & -84 & 0.22 & -0.63 & 2.12 \\
\hline West Germany & 1957 & -85 & 0.26 & -1.11 & -0.65 \\
\hline
\end{tabular}

Source: Authors. 
Table 5. Average Forecast Errors and Changes in Economic Trends (Foreign Experience Using M1)

\section{9 countries Excluding Outliers}
Constant
0.81
0.58

$\begin{array}{rrccc}\begin{array}{r}\text { Change in average } \\ \text { inflation rate }\end{array} & 0.26 & (9.04) & 0.33 & (2.42) \\ \text { R Squared } & 0.69 & 0.15 \\ \text { No. of Obs. } & 39 & 35 \\ \text { Degrees of Freedom } & 37 & 33\end{array}$

Note: "T" statistics are shown in parentheses.

Source: Authors. 
Chart 1. Average Forecast Errors and

Changes in Average Inflation

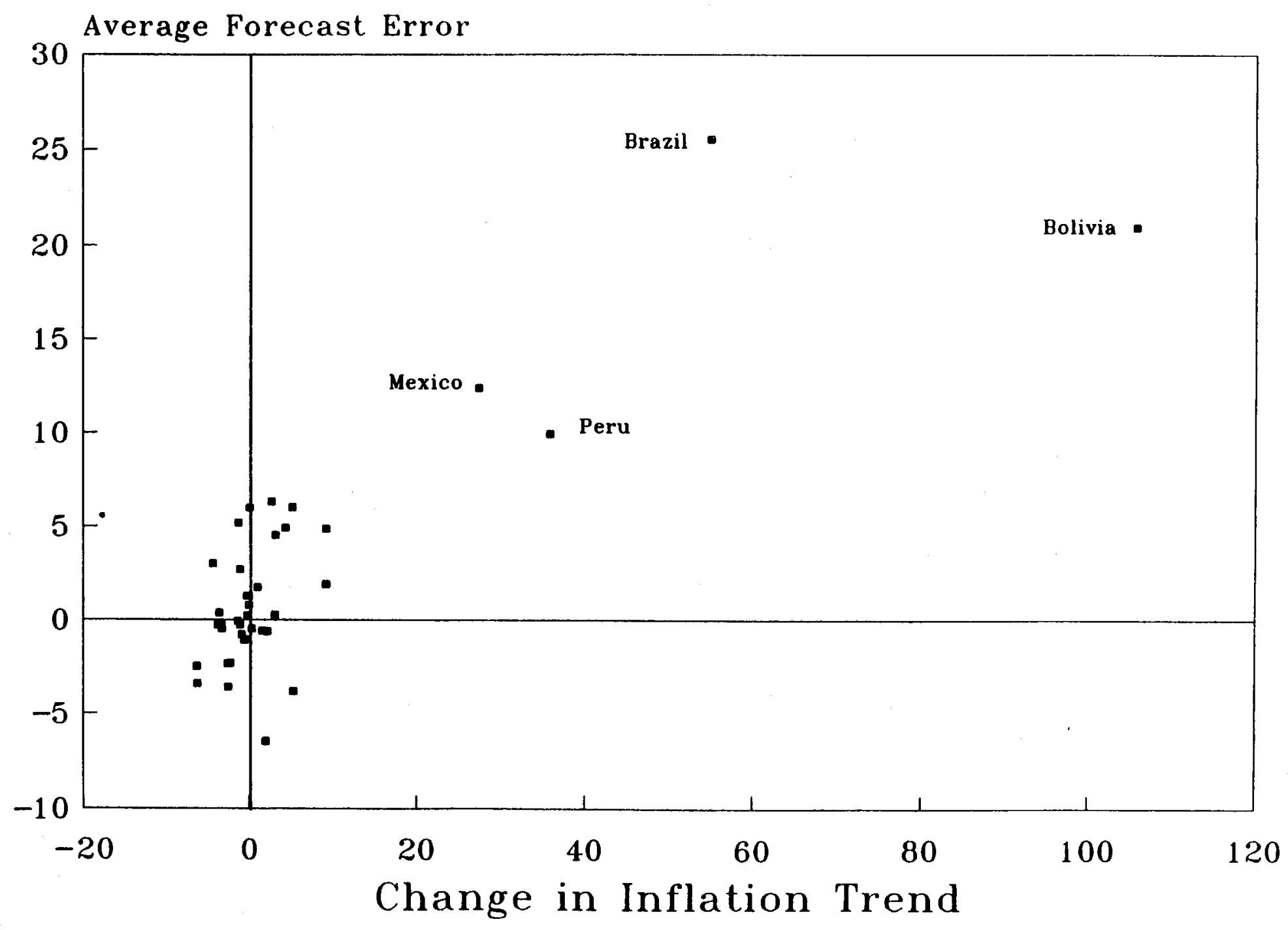

